\title{
Erödített középkori kolostorok és templomok kutatása Somogy megyében
}

\author{
M. ARADI CSILLA \\ SMKH-Járási Építésügyi és Örökségvédelmi Hivatal \\ H-7401 Kaposvár, Pf. 281, e-mail:csiaradi@freemail.hu
}

\begin{abstract}
M. ARADI, Cs.: The research of medieval fortified cloisters and churches in Somogy county.

Abstract: The paper deals with the various causes of fortification of churches and monastic establishments in Somogy county throughout the Middle ages.
\end{abstract}

Keywords: fortifications, value storage, written sources, archaeology, cemetery, Turkish wars

\section{Bevezetés}

A magyarországi erődtemplomok kérdésével sokan foglalkoztak, jelentős részben azonban a mai is álló, erdélyi erődtemplomok problematikáját kutatták. A javarészben ma már nem látható, csak levéltári források és régészeti kutatás, terepbejárás által lokalizálható erődített kolostorok és templomok kérdése jóval később került a tudományos kutatás homlokterébe. E kérdés öszszegzésére törekedett Tolnai Gergely, aki funkcionális szempontok figyelembevételével 2 csoportra osztotta az erődített templomokat és kolostorokat.

1. Az erődített templomokat és kolostorokat a lakosok (alapítók) saját védelmük érdekében építették ki, de az egyházak szakrális funkciója továbbra is fennállt.

2. A liturgikus feladatok megszünése után, a török elleni végvárrendszer, illetve hadszíntér részévé vált az épület, melyet erődítettek, vagy a kezdeti erődítéseket erősítették meg - ebben az esetben várrá alakított kolostorról vagy templomról beszélhetünk. ${ }^{1}$

Bár a Tolnai által felvázolt osztályozáson minden bizonnyal finomítani lehetne - (pl. számos adat alapján a végvárrendszer részévé váló kolostorok/monostorok egyházi használata még sokáig kimutatható), mégis e két típus megkülönböztetése szükségesnek látszik.

\section{A templomerődítések okai}

Mi okból erődítettek meg egy templomot a középkorban? Mi nevezhető egyáltalán erődítésnek, hiszen tudjuk, hogy a templom körüli temetőket eleve kerítették? A források alapján úgy tünik, hogy sokkal nagyobb számban találunk főleg a középkor második felétől valamiféle, sokszor kezdetleges erődítéssel rendelkező templomokat, mint eddig sejteni lehetett. Az erődítések létrehozásának talán legfontosabb kiváltó oka a török előtti időszakban a hatalmaskodások nagy számában rejlik, bár tagadhatatlanul a tatárjárás utáni időszaktól terjedtek el. A templom, mint a település legerősebb,

\footnotetext{
$1 \quad$ Tolnai 2001. 11.
}

ebben az időszakban már többségében szilárd építőanyagból készült épülete mentsvár szerepet is ellátott, illetve értékek (pl. oklevelek) őrzésére is szolgált. A mentsvár szerep ellen az egyház némely esetben tiltakozásának adott hangot (pl. az 1278-as budai zsinat határozatában hangsúlyozta, hogy „a pap a maga, vagy más holmiját a templomba ne tartsa, kivévén ha ellenség jő, vagy tűz támad, de akkor is csak addig, míg a veszély el nem múlt."), alapjában véve azonban az asylum jog alkalmazásával mégis szentesítette.

\section{Értékmegőrzés}

A templomok és templomkertek, temetők az írott források, és némely esetben régészeti bizonyítékok alapján egy másodlagos, nem egyházi funkciót is betöltöttek. Számtalan forrás őrizte meg számunkra azt a tényt, hogy a monostorok, kolostorok, káptalanok és a plébániatemplomok az oklevelek és más értékek megörzési helyei is voltak minden tiltás ellenére - ezek híján a család saját házában/kúriájában őrizte fontos iratait.

A konventeknek, hiteles helyeknek kötelességei közé tartozott az oklevelek őrzése. A somogyvári konvent az általa kiadott oklevelek másodpéldányait sekrestyéjében vagy levéltárában (sacristia seu conservatorio) tárolta. ${ }^{2}$ A toldi pálosok, a megelőző, batéi alapításra vonatkozó iratokat egy szekrényben (in scrinio claustri de Thold) tartották, ${ }^{3}$ hasonlóan a szerdahelyi pálos kolostorhoz. 1495-ben a kiskorú Dersfy Miklós panasza szerint Dancs Pál lányai a szerdahelyi pálos kolostorban egy kötelékekkel összekötött, nagy, öreg szekrényben őrzött, a család birtoklását igazoló iratokat kivették (mivel ez nem fért a szekérre), ládába tették, lepecsételték és elvitték. ${ }^{4}$ Egy 1303-as oklevél alapján, 3 évvel korábban, Gergely fia Boxa 25 nemessel Horpácsi Tamás fiainak parochiális egyházába tört, az egyház kapuját betörve a templomban őrzött pénzüket elvitték. ${ }^{5}$ 1319ben Kányán Ozorai Sándor rátört Kányai Fülöp és rokona Rádi Márk templomára és az ott őrzött privilegiális okleveleit és javait eltulajdonította. ${ }^{6} 1443$-ban Gordovai Fancs Péter familiárisaival Nagyatádon 28 jobbágytelket felégetett (valószínűleg faházakról volt szó), 215

2 SMM-B. 79. 119. DF 208970 (1485), 1379-ben a Pécsváradi konvent, 1384-ben, pedig a Kői konvent sekrestyéjében (sacriscia) örzött okiratokról értesülünk. ZO IV. 121, 272

3 Doc. Art. Paul. I. 209, II. 31

4 Ezeket egy év múlva Bornemissza János elvitte. (Tótfalu, Irefalva, Gyarmat, Veresalma, Bát, Szentbalázs, Szerdahely, Zarany, Sárd, Csokonya ügyében.)

5 AOT I. 211

6 AOT IX. 47. DL 86970. 
ökröt lovakkal, tehenekkel elhajtott, a plébániaegyházat feltörte, és onnan kelyheket, papi ruhákat és egyéb ja-

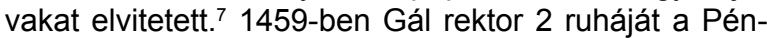
tekhelyi templomba helyezte el, hogy nehogy ellopják. A templom kulcsait káplánja, Demeter őrizte, a ruhák mindazonáltal így is eltüntek. ${ }^{8}$

A felsorolást más megyékből fennmaradt adatokkal is folytatni lehet. 1444. június 10 -én a veszprémi káptalan garabonci birtokát megtámadták, a plébániatemplomba hatalmaskodva betörtek, és Mihály plébános, valamint a helybeliek biztonságosabb megőrzésre ott elhelyezett javait (500 Ft értékben) elvitték. ${ }^{9}$ 1482-ben a Zalaszentmihályi templom kapuját ugyancsak tönkre téve, a törökök a Szentbalázsi család birtokaikra vonatkozó okleveleit - amelyet a biztonságosabb megőrzés végett helyeztek ott el - az egyház más holmijával együtt elvitték, az egyes okleveleket széttépték, így azok elkallódtak. ${ }^{10}$ Talán hasonló, értékmegőrző szerepet látott el a Ny-i karzat. A korábbi kutatás a kegyúr helyeként rekonstruálta ezt a területet, de az okleveles források alapján azt az oltár közelébe helyezhetjük.

\section{Refugium funkció}

A templomok nemcsak a javak és oklevelek őrzésére voltak alkalmasak, hanem veszély esetén mentsvár szerepet is betölthettek. 1318-ban az esztergomi érsekség területén a Pogon folyó mellett emelt, a Mindenszentek tiszteletére szentelt oratorium kegyurai jogot nyertek arra, hogy magukat gyermekeikkel, szegényeikkel és javaikkal zavaros időkben az imaházban megőrizhessék. ${ }^{11}$ 1347-ben a Felső-, és Alsódörögdi nemesek a Felsődörögdi Szt. András templom közös használatáról egyezkedtek - amely szerint a föoltárnál, illetve a Boldogságos Szűz Mária oltárnál a Felső, míg a Szt. Domonkos oltárnál az Alsódörögdi nemesek kaptak helyet, akik a templom D-i szegletébe temetkeztek, és baj esetén vagyonukat ők és jobbágyaik szintén ide menekíthették. ${ }^{12}$

Úgy tünik, hogy a konventeket leszámítva, az oklevelek tezaurálása összefügg a magánegyházi funkcióval is - a föúri alapítású monostorok, valamint nemesi alapítású plébániatemplomok egyfelől nagyobb biztonságot ígértek, másrészről a család életének részét is képezték, akár a család temetkezési helyeként, akár pedig birtokának tartozékaként jelennek meg. Ugyanakkor ellenpéldával is találkozunk - a Szerdahelyi család a Szentjakabi apátság birtokainak bizonyítékául szolgáló okleveleit (többek között alapító iratát is) magánál őrizte, nem kis részben azzal a céllal, hogy e birtokokat saját kezelésébe vegye. ${ }^{13}$

7 DL 103599 A hatalmaskodás során, az atádi vásárra árúkkal igyekvö, szabási jobbágyokat is kifosztottak. Rácz 2001. 64.

8 Békefi 1907. 107.

9 SMM-B. 89. 13. DF 201298

10 SMM-B. 83. 64. DF 268237

11 AOM I. 451-3, AOT V. 13

12 Valter 2004. 98-99.

13 Kumorovitz 1964. 65. 1298-ban elrendelték az oklevelek visszaszolgáltatását.

\section{A temetők másodlagos szerepe}

A középkori források szerint a temetőkben pincék, gazdasági épületek is előfordultak. 1420-ba a szentpéteri pálosoknak történő adományozás kapcsán, Szentpál faluban, a Szt. Pál apostolról elnevezett temető oldalába épített pince szerepel: „unum cellarium ad latus cimiterii de S. Paulo”.14 1435-ben a Szakácsi plébániatemplommal szembeni kúriatelekröl esik szó, valamint „parte cuiusdam cellarii in cimiterio dicte parochialis ecclesie.” Borsa Iván ezeket a temetőben lévő kriptákként értelmezte, azonban valószínűbbnek tünik egy tárolóhelyiség/pince feltételezés. ${ }^{15} \mathrm{Nem}$ egyedi somogyi szokásról volt szó, hiszen 1411-ben a szlavóniai Gragenaszentmiklóson a temetőn belül szintén álltak házak és pincék, ${ }^{16}$ 1417-ben pedig Ókörös mezővárosának bírája adta el a plébániatemplom temetőjében a pincék között álló, tanácsháznak is alkalmas sírkápolnáját. ${ }^{17} \mathrm{~A}$ budai Nagyboldogasszony egyház temetőjében is állt egy ház. ${ }^{18}$

\section{A 14-15. századi templomerődítések régészeti nyomai}

2000-2001-ben Balatonszárszó DK-i határában, az ún. Kiserdei-dülőben, a valamikori temető mellett, az M7es autópálya nyomvonalának tisztázása során kezdődött meg a középkori Szárszó falu templomának feltárása. (1. ábra) Belényesy Károly vezetésével egy ötszög alakú, 4-5 $m$ széles és $2 m$ mély árokkal és feltehetően sánccal övezett temetőt tártak fel, amely területen belül a 14-15. században, az árokra merölegesen, $7 \mathrm{db} 15 \times 5$ m-es, cölöpváz-szerkezetes, paticsfalú, egymáshoz épült, 3 osztatú házat találtak, amelyek temetkezéseket vágtak át. A D-DK-i oldalon további 8, egyterü épület egy, az árokkal párhuzamos, $17 \times 7$ m-es, mély alapozású, kétosztatú épülethez kapcsolódott. A lakó- és gazdasági jellegü épületek egy tömbben, a védettebb $D$-i oldal mentén helyezkedtek el, az ÉK-i oldalon pedig ideiglenes lakóházak létesültek, K-en két egyterü pinceépülettel. Az ásató menedékként, refugiumként értelmezte az épületeket, ahová a lakosság veszély esetén javaival együtt menekülhetett. A templomhoz közelebb, kb. 20 m.-re, a temető korábbi körítőárkát is megtalálták, melyet a későbbi árok építésekor temettek be. A korai cínterem határán belül sikerült nagyméretű, késő Árpád-kori tárolóvermeket feltárni, melyek néhányszor a templom körüli temetkezéseket, vagy a temetőárkot megbolygatták. Az erődítést a 15. században felgyújtották, ám a később elplanírozott területet a 18. századig temetőként használták. ${ }^{19}$ Talán hasonló lehetett az elrendezés a $6 \mathrm{~m}$ széles, $3 \mathrm{~m}$ mély, $\mathrm{V}$ alakú árokkal övezett Balatonszabadi-Pusztatorony nevű lelőhelyen megkutatott templom és temető esetében is (Magyar Kálmán ásatása 1982-3). (2. ábra)

\footnotetext{
14 Rupp I. 317. Az adományozó Szentpálfalva bírája, Imre volt. (iudex de Sancto Paulo prope Strigench)

15 SMM-B. 2002. 896. oklevél. DF 2626615

16 ZSO III. 75. sZ.

17 ZSO IV. $978 . \mathrm{sz}$

18 Kubinyi 2005. 16.

19 Belényesy-Marton-Oross 2002. 9-14
} 


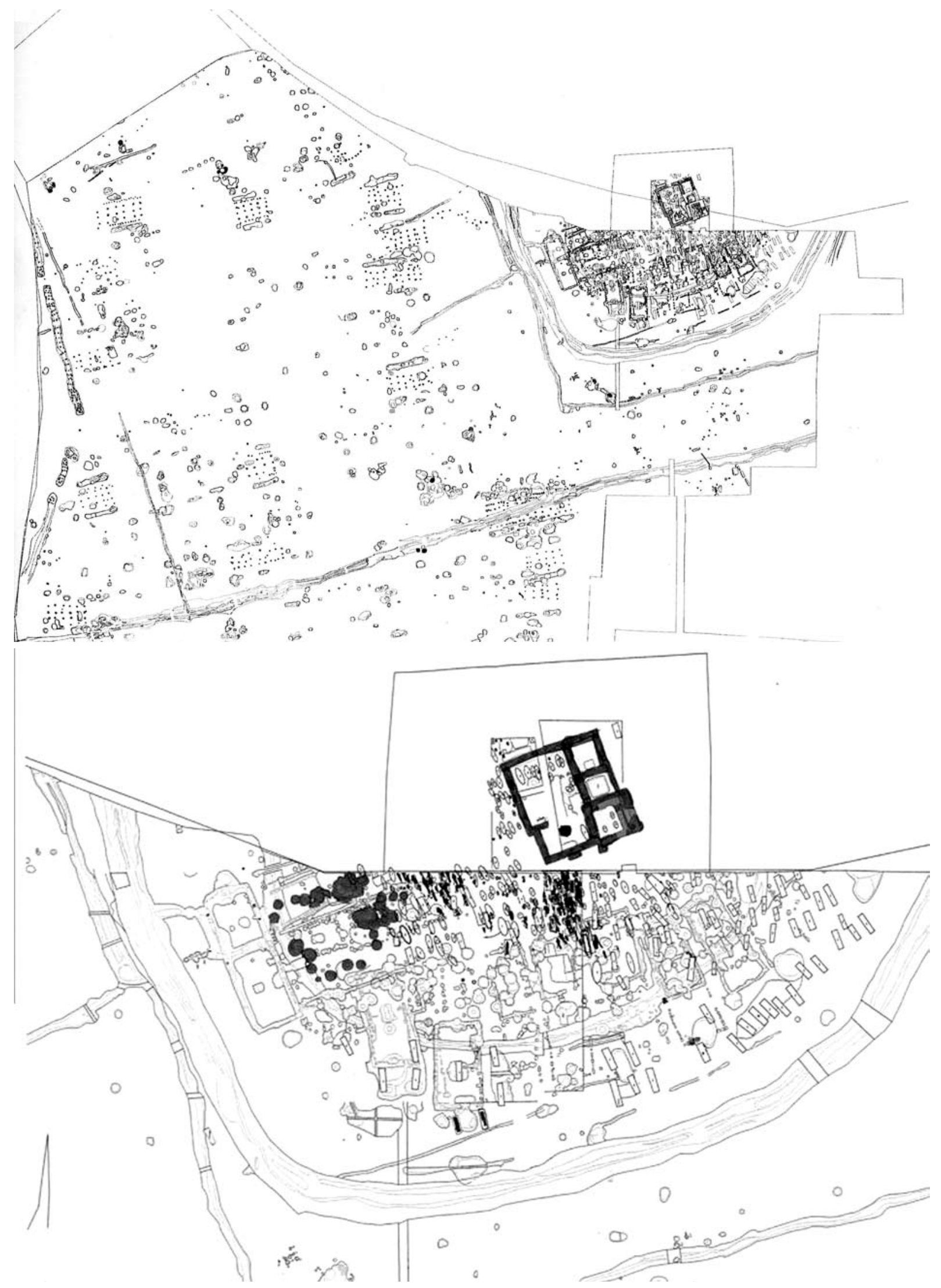

1. ábra: Balatonszárszó erőditett temploma (Belényesy Károly ásatása) 


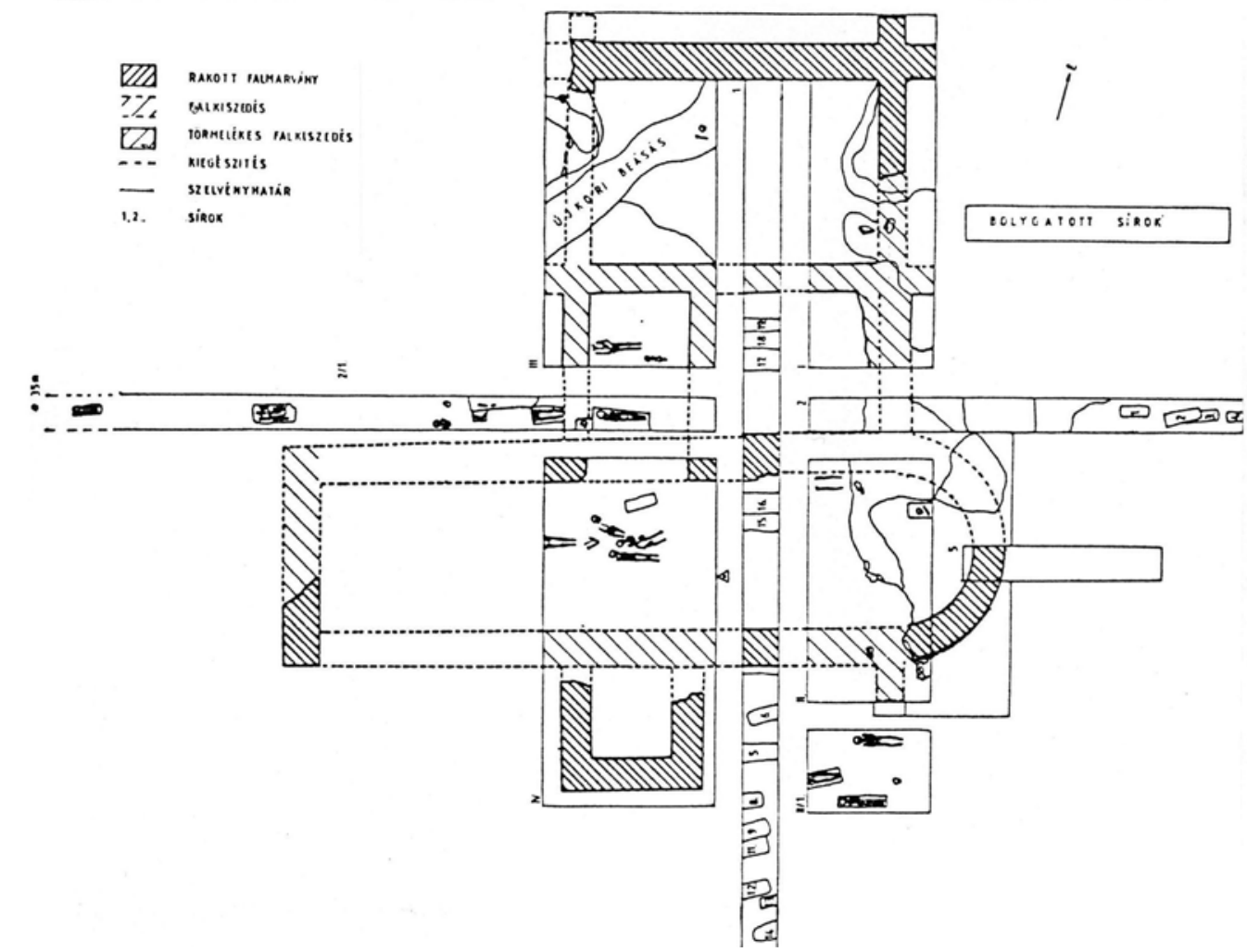

2. ábra: A Balatonszabadi-Pusztatoronyi templom ásatási helyszínrajza (Magyar Kálmán ásatása)

Veszprémfajsznál az Árpád-kori temető feletti rétegből, illetve a késő középkori sírok alatt, a körítő falnál 2 verem, valamint egy élelmiszertárolásra alkalmas cölöpszerkezetes építmény állt. ${ }^{20}$ Bár az ilyen jellegű építkezéseket tiltotta a budai zsinat (1278), a jelek szerint ez nem sok eredménnyel járt. ${ }^{21}$

\section{Templomerődítések az írott források alapján}

A kő templomok várszerü megerősítése - a kegyúr és családjának, illetve javainak védelmére - nem volt ismeretlen a középkori forrásokban. Templomból emelt erösség állt a Zala megyei Tapolca oppidumban (bár itt a templom mellett épült kúriát is belefoglalták az erődítésbe). A Városlődi karthauziak perjele Szilveszter megegyezett Gersei Lászlóval és Petővel a város elpusztítása és a Mária egyházból emelt erősség lerombolása dolgában „...fortalicii ex ecclesia beate Maria virginis erecti." 1463-ban egy hatalmaskodás során a Baranya megyei Jenő temetőjét ostromolták meg. ${ }^{22}$ Egy 1468 körül keletkezett oklevélben a Liptó megyei Szentmáriai egyház erődítésében lakozó Rásztoki István nemesről esik szó „residens in fortalitio ecclesie ad Beatam Virginem". 1478-ban a Sáros megyei Kucsinban Perényi Miklós adományából erősítették meg a templomot „ecclesiam...obsedisse et fortalicium erigere". 1302-ben az Osl nemzetség birtokeladásában a Sopron megyei Martonfalva esetében pedig templomának erődítetlen voltát, mint különlegességet emelték ki (ecclesia incastellata). ${ }^{23}$

Somogy megyében e korai korszakhoz tartozó erődítések körébe a fent említett, és régészetileg is bizonyított példákon kívül más, eddig csak terepbejárás során azonosított egyházak is tartoztak.

\section{Terepbejárásokkal azonosított erődítésnyomok}

Tömörd falu sánccal és árokkal övezett templomat Szőlösgyörök-Kopaszberek határrészen azonosította Müller Róbert. ${ }^{24}$ Karád-Fehéregyháza dűlőben szintén sáncok vették körül az egykori templomot. ${ }^{25}$ Nagyberényben a $100 \mathrm{~m}$ magas Temetődombon az egyházat kör alakú, 15-16 m széles és 3-5 m mély vizesárok és sánc vette körül - ez alkotta a belső várat. $A$ vár 2 részes volt és az egész hegytetőt magába foglalta. A külső vár $D$-i végén ugyancsak nyomon követhető egy árok vonala. ${ }^{26} \mathrm{~A}$ valamikori Jódi templom a vele azonos nevű szőlő K-i szélén Török templom néven ismert - maradványait sánc övezte. ${ }^{27}$ Az Algamási, sánccal körülölelt templom Balatonlellétöl D-re az Illés tetőn

\footnotetext{
23 Mező 1996. 32, AOT I. 144, Tolnai 2001. 23

24 RRM Adattár II/12/127

25 RRM Adattár I/15/7, 776. Draveczky B. terepbejárása 1963

26 Magyar-Nováki 2005. 96. (Kerék-hegy), RRM Adattár I/24/11, 4416-Bárdos E. jelentése, SMFN 46/137, Pesty 2001. 222.

27 SMFN 34/139, Pesty 2001. 169.
} 
állt. ${ }^{28}$ Lengyeltóti templomának erődített voltára egy 1870 körüli ábrázolásból következtethetünk (Greguss János metszete). Az egykori hadút mellett, a helység legmagasabb pontján álló templomdombot a 18. sz.-ig őrhelyként hasznosították és sáncokkal övezték. ${ }^{29} \mathrm{~A}$ felsorolt templomok erődítésére nézve okleveles forrásaink nincsenek, pontosabb keltezésüket csak régészeti ásatással lehetne eldönteni.

\section{Erődített bencés monostorok a megyéből}

A korai erődítések sorát 3 bencés monostorral zárhatjuk, melyeket a török elleni háborúk során újabb megerősítéssel láttak el és várként használtak.

A szentjakabi monostor erődítését 2. periódusú építkezései során kapta, a 14-15. sz. fordulóján, a templom és a kolostor gótikus átépítése nyomán (Nagy Emese ásatása 1960-66). (3-4. ábrák) Az újonnan kiépült kolostorszárny $\mathrm{Ny}$-i felét erős támpillérekkel erősítették meg (ez eredetileg az 1. periódusú kolostor körítőfala volt), így védőfunkciót is betölthetett. Komolyabb erődítése a 16. sz. elejére keltezhetö - ekkor a monostor K-i zárófalán kívül külső téglafalat húztak fel - ekkortól datálódik várfunkciója. 1500-ból az apátság várnagya, castellanusa ismert. ${ }^{30}$ 1548-ban a helytartótanács tervezete, mint szóba jöhető erődítéssel számol a kolostorral, 1555-ben pedig Nádasdy Tamás nádor Kapos és Mére (Kaposmérő) várával együtt sorolja fel. ${ }^{31}$ Ugyanebben az évben török kézre került, mivel védői elfutottak. A törökök még 1664-6-ban is használták - amikor Evlia Cselebi török utazó is felkereste. ${ }^{32}$
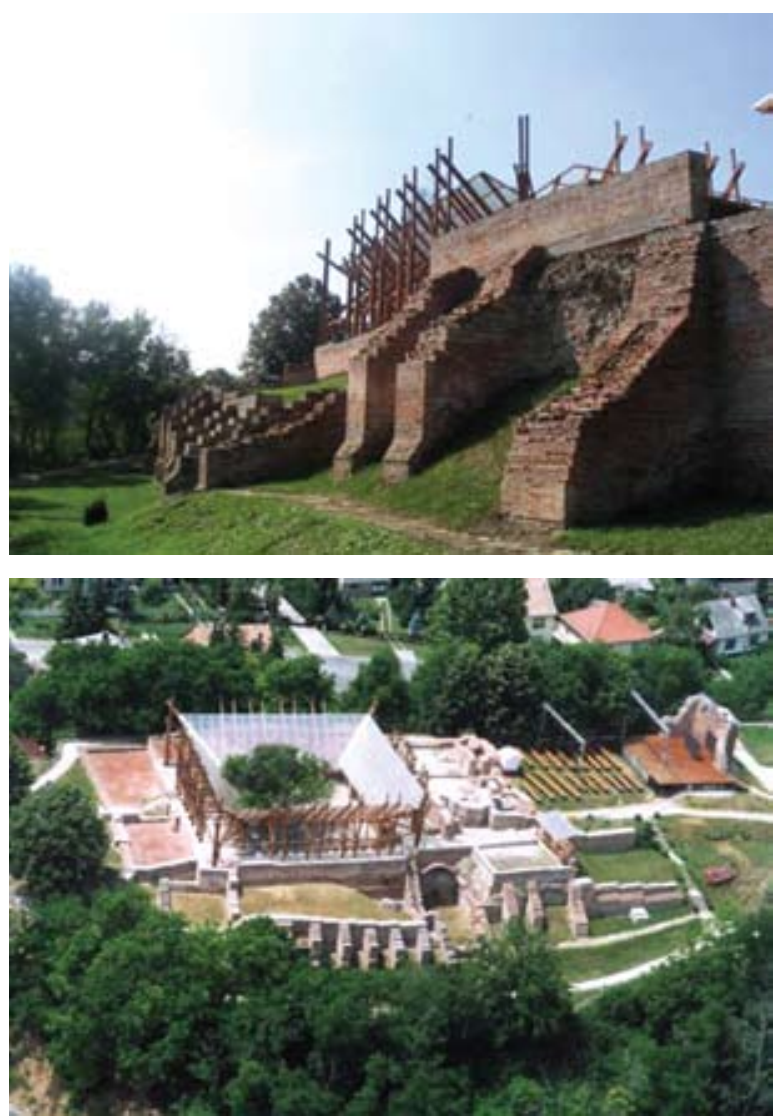

3. ábra: A szentjakabi bencés monostor keleti oldalának erődítése (légifotó: Civertan Bt.)

A Szt. László által alapított somogyvári bencés mo-

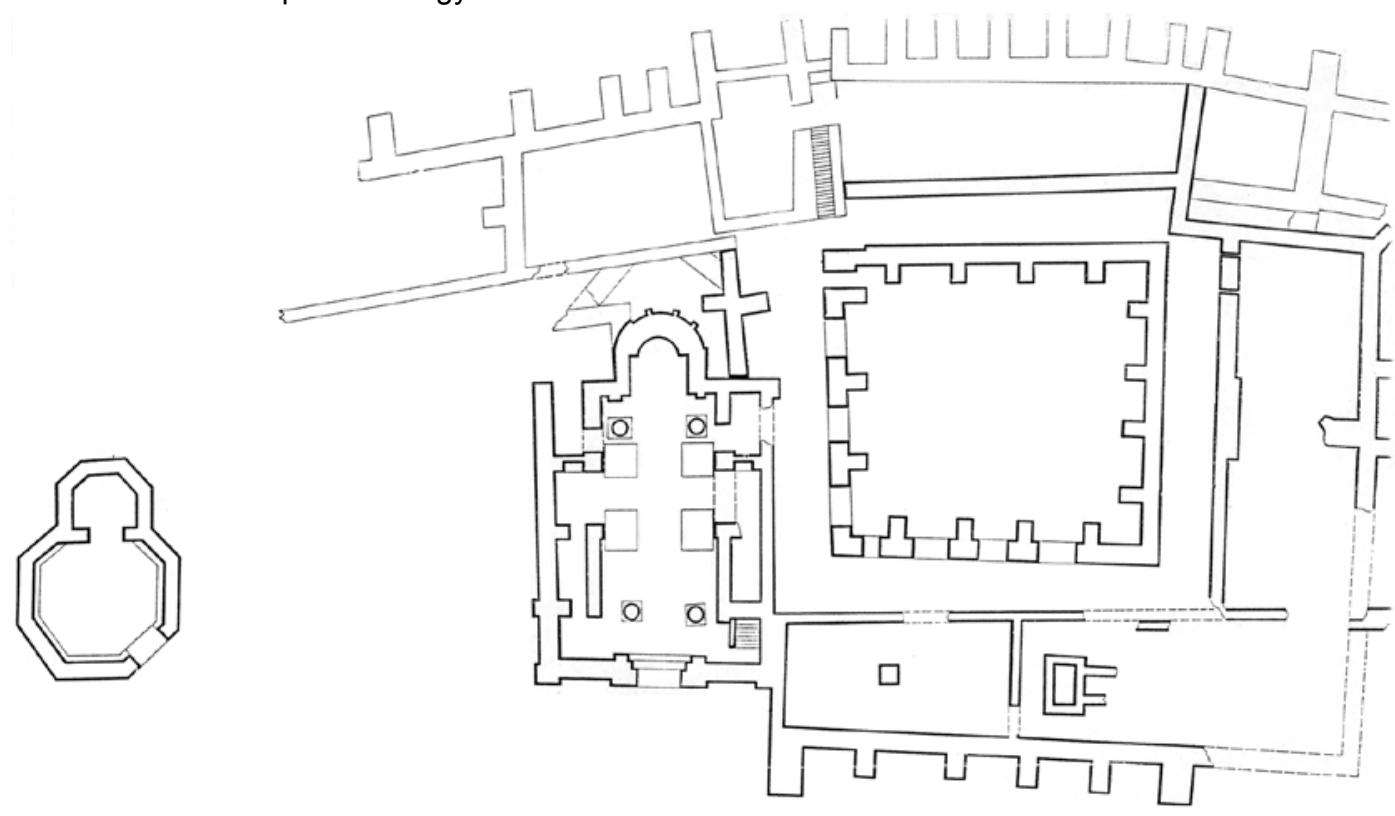

28 SMFN 2/246, 267, 54-4, RRM Adattár II/2. 121

29 Magyar-Nováki 2005. 161-2, Lukács 1992. 21, 26, B. BenkhardLukács 1996. 1-2. A templom müemléki és régészeti kutatását $B$.

4. ábra: A bencés monostor alaprajza Benkhard Lilla és Lukács Zsuzsa végezték 1989-90-ben.

30 SMM-K. 79. 52. DL 2097

31 Pálffy 1999. 103, 118.

32 Csorba 1974. 31. 
nostor eredetileg a sánccal övezett, korai ispánsági székhelyen létesült. (5-6. ábrák) Az erődítésnek bronzkori előzményei is vannak. Az erősséget a fennsík felől 2 árok határolta, melyek között $5 \mathrm{~m}$ magas sánc húzódott. A monostor feltárását 1972-89 között Bakay Kornél végezte, majd 2002-ban a törökkori erödítés $7 \times 7$ m-es, négyzetes DK-i saroktornyát, valamint az ispánsági vár részét alkotó fagerenda szerkezetü sáncfalakat kutatta meg, míg 2008-2009 között a monostort övező sáncárkot vágta át. ${ }^{33}$ 1535-ben erődítették, 1543-tól végleg harcászati jelentősége lesz, ekkortól tornyát bástyaként hasznosítják és a kolostor vizesárkát, sáncát megújítják. Somogyvár stratégiai fontosságát I. Ferdinánd is felismerte, aki 1543-ban némi pénzsegélyt adott és 15 lovas, valamint 20 gyalogos felfogadását engedélyezte. $A$ várat 3 oldalról mocsár övezte, bejárata $D$ és $K$ felöl nyílott. Az 1546:44 tc. alapján a király kötelessége volt a várról való gondoskodás, ekkor 25 lovassal és 50 gyalogos katonával birtt. ${ }^{34}$ Somogyvár őrségének tervezett létszáma 1548-ban 32 gyalogos, míg a következő évben 24 hajdú, akiknek zsoldja $575 \mathrm{Ft}$-t tett ki. ${ }^{35}$ 1550-ben tovább növelték a létszámot, 32 huszárról és ugyanennyi gyalogosról tudunk. Ezzel együtt a szerzetesek 1554-ig lakták az apátságot ${ }^{36}$ (apátja 1555-ig szerepel), a konvent munkájára pedig 1539-ig van adatunk. ${ }^{37}$ 1553-ban attól rettegtek „ha Somogyvárt a török megépíti, jaj Kanizsának, Csurgónak, sőt vége lesz Pettaunak, az egész vidéknek". ${ }^{38}$ Az 1555-ös háborút követöen a király a kolostort (vagy legalábbis annak egy részét) felrobbantotta. 1557-től Csányi Ákos Somogyvár megerősítését szorgalmazta, míg 1560-ban már abbéli félelmének adott hangot, hogy a török az erősséget újra megépíti, ezért a szentegyház lerombolását javasolta. ${ }^{39}$

Feltételesen az erődített monostorok körében említ-

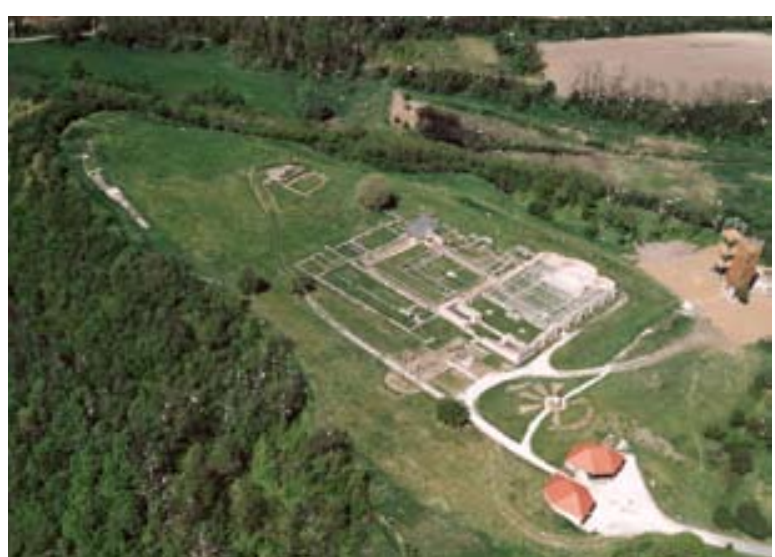

5. ábra: A somogyvári bencés monostor légifotón (Civertan Bt.)

33 Magyar-Nováki 2005. 132.

34 Csorba 1974. 18-19, Pálffy 1999. 49

35 Pálffy 1999. 103.

36 PRT XII/B. 163-4

37 PRT XII/B. 165, ETE V. 426, 513.

38 PRT XII/B. 165, Csorba 1974. 19.

39 A keszthelyi ferences kolostorhoz hasonlóan. Öze 1996. I. 60, II. 227-8.

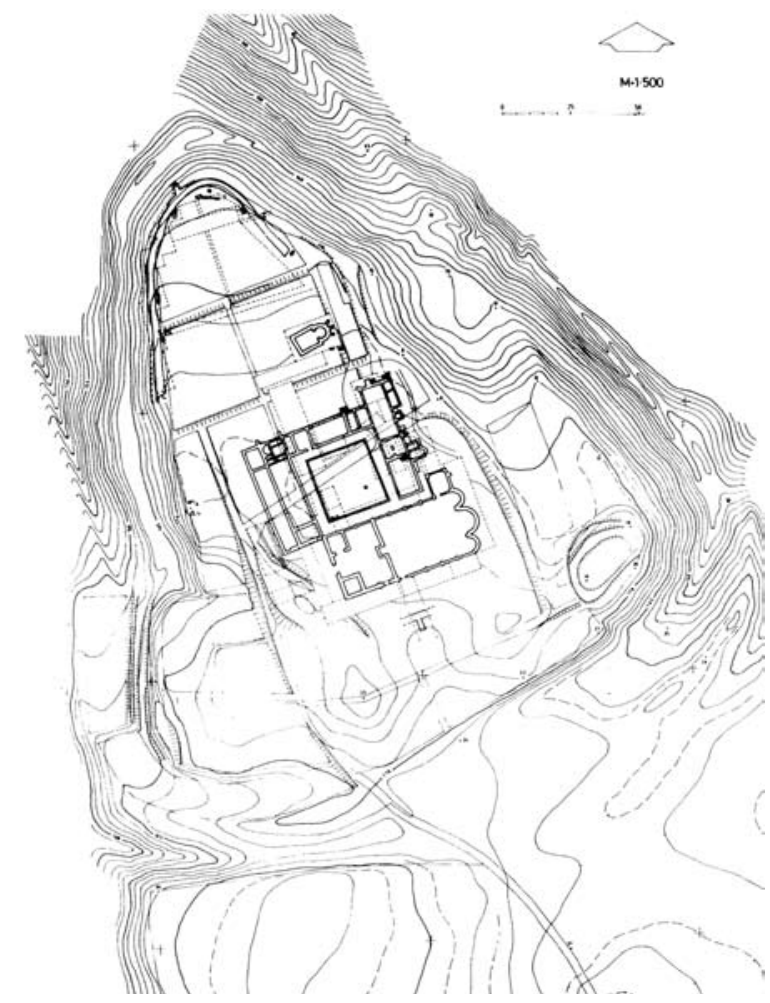

6. ábra: A monostor és erőditésének helyszinrajza (Bakay Kornél ásatása)

hetjük a Babócsai Szt. Miklós bencés apátságot is, amelyet, a föúri kúriát is magába foglaló téglalap alakú sánccal és árokkal erődítettek meg a 14. sz.-i átépítés során. Az erődítményről K-en 2 árokkal és sánccal egy elővárat választottak le, Ny-ról pedig a Rinya magaspartja határolta. A Basa-kert (Nárciszos) néven ismert lelöhelyet Magyar Kálmán 1984-1992 közötti feltárása alapján ismerjük. Az 1989 évi sáncátvágás felfedte, hogy a sánc 2 vízszintes gerendasor közötti földtöméssel készült, ami előtt $\vee$ keresztmetszetü, 3-4 m mély árok húzódott. A sáncok anyagfeltöltését függöleges karósor erősítette, míg köztük vízszintesen elhelyezkedő merevítő gerendák nyomait találták. A sánc feltöltéséből 13-14. sz.-i kerámia került elő. $A$ sáncot a török háborúk idején is használták, mivel a 17. sz. végéig folyamatosan megújították, sarkaira ekkor félköralakú, bástyaszerű kiszögellések épültek. Kapujának nyomait É-i és D-i oldalán lehetett megfigyelni. Feltehetően a vele szemben álló Babócsai vár ellenerődje lehetett. ${ }^{40}$

\section{Harcászati jellegű erődítések a török elleni háborúk időszakából}

A bencés monostorokkal már meg is érkeztünk a templomok erődítésének második korszakába, a török elleni háborúk időszakába. Az erődítések megalkotására rendelkezésre álló időszak rövidségének miatt kialakított, főleg sánc és palánk védművek egész sorát is-

40 Jankovich 1976. 28, Magyar-Nováki 2005. 20. 
merjük a Balaton környékéröl. ${ }^{41}$ A templomok harcászati jelentőségét szilárd építőanyaguk és tornyuk biztosította. ${ }^{42} \mathrm{~A}$ hadműveleti területre került templomokba reguláris örséget helyeztek el, így a végvárvonal részeivé váltak. Kialakításuk sem tért el végvárak erődítésétől, amelyet mennyiségi szempontból erősítettek, így téve sürübbé a végvári vonalat.

Az 1540-es évek második felében a Balatontól D-re fekvő területen összesen 454 huszár és 552 hajdú látta el a védelmet. Nádasdy Tamás dunántúli főkapitány, (1554-től nádor), majd Késás Pál feladatkörébe tartozott a védelmi célokra nem használható kolostorok lerombolása. Hasonlóan döntött 1552-ben Königsberg, majd egy évtizeddel később Gall és Salm a Győr környéki romba dőlt templomok elpusztításáról, vagy a védelmi rendszerbe való bekapcsolásukról. ${ }^{43}$ Győr környékéröl így több, a várláncolatba bevont erődített templomról van tudomásunk (Félegyháza, Baráti és Mérges templomai). Harcászati jelentőségük hegytetőn való elhelyezkedésük miatt adódott, és mint tarisznyavárak, górék láttak el funkciót. ${ }^{44}$ Az 1570 -es években két egyház, Kenese és Kajár templomának lerombolásáról tudósítanak a források. ${ }^{45}$

A Dunántúlon nagy volt a végvári rendszerbe tartozó erődített kolostorok száma. (Csorba Csaba innen 22 esetet említ az országos további 21 esettel szemben. $)^{46} A z$ egyházi tulajdonba lévő épületeket az 1550-es évektől bérelték, vagy zálogba vették és katonai célokra alakították át. Amely templomokat, kolostorokat nem erődítették, azt felrobbantották, nehogy a török építse fel. A kolostorok, föleg a bencés monostorok pusztulása a 15-16. sz.-ban jelentős méreteket öltött, a rendházak nagy része ebben az időben már világiak kezén, kommendátorok kezelésében található, amint erről az 1508-as vizitáció is beszámol. Csorba Csaba Mohács előtt 30 kolostor erődítettségére talált adatot, amelyek fele bencés monostor. ${ }^{47}$ A szentjakabi, a somogyvári, a pannonhalmi, a tihanyi, a zalavári, a kapornaki és a dömölki bencés apátságok mellett a keszthelyi, a csákányi és a segesdi ferences, a mesztegnyői domonkos, a lövöldi karthauzi, a szentpéteri pálos és a csurgói johannita kolostorok játszottak szerepet a védelemben, míg a hedrehelyi ferences és a zirci ciszter kolostort a török kívánta őrházzá építeni. ${ }^{48}$

41 A dél-dunántúli kolostorok török elleni erödítésének kérdését Csorba Csaba dolgozta fel. Ld. Csorba 1974.

42 E tornyok harcászati jelentősége azonban nem volt minden esetben kielégítő, pl. Zalavárnál az apátsági templom tornya még nagyobb széljárás esetében is megingott. Öze 1996. I. 17. A zalavári monostor erőditésének 1557-es megújításáról szemléletes képet kapunk Mezőlaky Ferenc Csányi Ákoshoz írott leveléből. Csorba 1974. 20.

43 Pálffy 1999. 52, 74, 87. A tapolcai erődített templomot és a karthauziak lövöldi kolostorát 1554-ben kiiktatták a védelmi rendszerböl, és az utóbbi lerombolását is elrendelte Pallavicini, mivel őrséggel való ellátása nehézségekbe ütközött.

44 Pálffy 1999. 170-1.

45 Pálffy 1999. 126.

46 Csorba 1974. 14.

47 Csorba 1974. 15.

48 Pálffy 1999. 126.

\section{A 16. században erődített somogyi kolostorok és templomok}

Az 1530-as évektől egyre-másra tűnnek fel írott forrásaink a dunántúli erődített kolostorok kezdetben még a kolostori élet kísérőjeként. A Helytartótanács 1548 évi tervezetében felsorolt kisebb erősségek, köztük erődített kolostorok és templomok, (Szentjakab, Fonyód, Bajom, Mesztegnyő, Szőcsény, Csákány, Marót) megszemlézését, valamint a védelem szempontjából haszontalanok lerombolását írta elő. ${ }^{49}$ Ugyancsak fontos adalékkal szolgál Nádasdy Tamás 1555. március 8.-án kelt jegyzéke a Dunántúl megerődített helyeiről és birtokosairól, köztük Szentpéter, Csurgó, Babócsa, Balatonszentgyörgy, Marót, Marcali, Mérő, Fonyód, Csákány, Mesztegnyő, Segesd, Szentjakab, Bajom erősségeiről. ${ }^{50}$ Szigetvár, és ehhez a védelmi vonalhoz tartozó somogyi várak eleste után (1566) a Dél-Dunántúlon újra kellett szervezni a védelmi vonalat Kanizsa körül, így a korábbi templomokból és apátságokból kialakított erősségek hangsúlyosabb szerephez jutottak (Id. Keszthely, Fonyód, Csákány, Szőcsény erődítését).

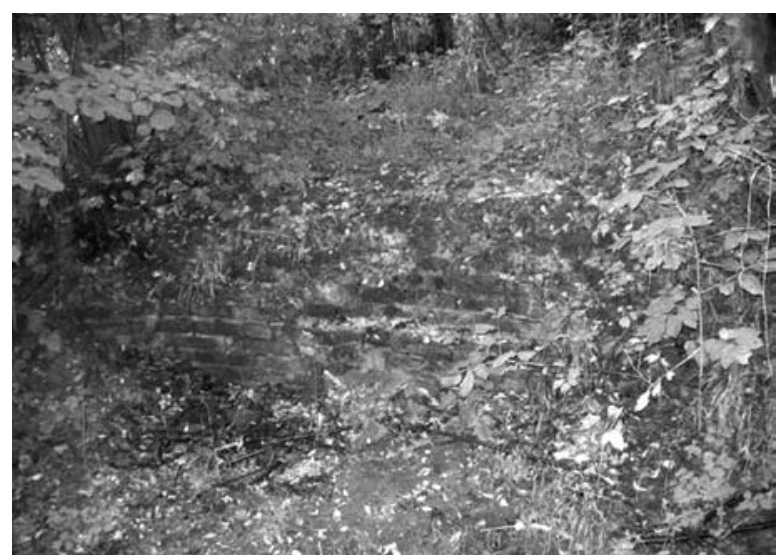

7. ábra: A hedrehelyi ferences kolostor maradványa

Hedrehelyen a ferences kolostorban (Magyar Kálmán 1973. évi ásatása) 1535 elején még 17 szerzetes élt, ${ }^{51}$ 1546-ra azonban már elhagyták. 1550-ben és 1554-ben a kolostor lerombolását javasolják. ${ }^{52}$ (7. ábra) 1557-ben Hedrehely városában még élt egy öreg szerzetes, akit 1561-ben gyilkolt meg Kis Ferenc. ${ }^{53}$ Később török kézre került, erődítését ekkor építették ki. A kül-

\begin{tabular}{ll}
\hline 49 & Pálffy 1999. 103. \\
50 & Pálffy 1999. 117-8. \\
51 & Karácsonyi II. 74. \\
52 & Karácsonyi II. 74, ETE V. 307.1550 márc. 3. Somogy megye leve- \\
le Terjék Tamás kanizsai várnagyhoz így szólt: „Certa fama allata \\
est ad nos, quod ipsi Thurci nituntur et volunt claustrum fratrum \\
Beati Francisci in Hederhel edificare et possidere, si autem ipsum \\
claustrum ipsi Thurci edificaverunt, certum est, hunc comitatum \\
Simighiensem totum occupabunt, unde etiam aliis confinis \\
periculum imminebit.” A megoldást a kolostor lerombolásában lát- \\
ják, nehogy: „...ipsi Thurci amplius attentarent ipsum pro castro et \\
fortalicio edificare...”. \\
53 Büntetésképpen Kis Ferencet Szenyérben kivégezték. Öze 1996. I.
\end{tabular} 52, 317-319, II. 239. 
ső védelmi vonal maradványai, - 20 m-enként 1,5 m magas kerek tornyok, valamint a romoktól K-re 50-100 m-re földsánc - a kolostortól ÉK-re a visnyei út mentén húzódott. Egy 17. sz.-i leírás 20 lépés széles árokról és kettős földerődítésről szól. Az erődítés végső pusztulása 1695-ben következett be.

1555-ben Nádasdy Tamás a dunántúli magyar végvárak felsorolásában Csákány és Mesztegnyő kolostorát említi, Zrínyi Miklós 1558-ban Nádasdyhoz írott levelében pedig a töröknek a Mesztegnyői kolostort megerősítő munkáiról számolt be. ${ }^{54}$ Már 1548tól értesülünk a kolostor harcászati jelentőségéről. ${ }^{55}$ Orosztonyi Péter szenyéri várkapitány ugyanebben az évben oly erősnek írta le a kolostort, hogy azt csak ágyúzással lehetne lerombolni. ${ }^{56} \mathrm{Az}$ erődített Mesztegnyői domonkos kolostor a mai település $\mathrm{Ny}$-i szélén, az ú.n. Kraston dombon állt.
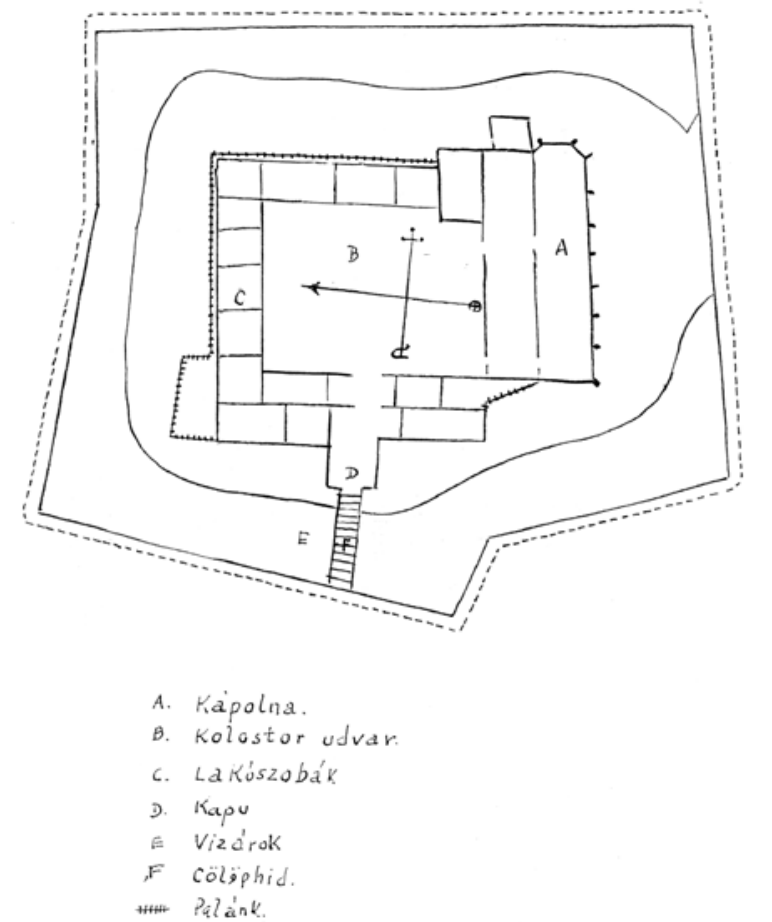

\section{8. ábra: A csákányi ferences kolostor Giulio Turco felmérésén}

A Csákányi ferences kolostort 1544 körül az Allya család alakította át katonai célokra, ekkor épült ki a Giulio Turco ábrázolásában látható tornyos várkapu a vizesárokkal. (8. ábra) Ábrázolása alapján a kolostort javarészt sánc övezte, csak kisebb, É-i részén találunk kettős palánkot. 1544-ben még hallunk gvardiánjáról (Szentlászlai Egyed), később azonban hadászati szerepe kerül előtérbe. ${ }^{57} 1555$-ben Korotna török kézre kerülésekor 18 szakállas puskát szállítottak az erődí-

54 Csorba 1984. 19, 68. lábjegyzet

55 Öze 1996. I. 58-59, Magyar-Nováki 2005. 162

56 Magyar-Nováki 2005. 162-163.

57 Dornyai 1937. 210-211. tésbe, ugyanekkor Csányi Ákos lerombolására tett javaslatot „Csákányt eltörni, kibe csak lopni, embert kínozni vagynak, sem erőssége, sem helye, hogy valamit szolgálhatna a földnek." 58 1556-ban Székely Lukács és Jakab lovasai lakják. 1566-ban Szigetvár elestekor magyar örsége felgyújtotta. ${ }^{59} 1567-$ ben a töröké, azonban 1568-ben már ismét magyar kézen találjuk. 1570ben Musztafa pasa Thury Györgyöt vádolta Csákány és Szőcsény felépítésével. ${ }^{60}$ 1572-be Palat Jeromos kanizsai építőmester tartott szemlét a várban. Leírása szerint egy 8 láb mély árok övezte, tornyából pedig Segesdig lehetett látni. ${ }^{61}$ 1576-ban kapitánya, Battyány István a gyalogság elmaradt bére miatt panaszkodik. ${ }^{62}$ 1580-ban a segesdi török örség sikertelen támadást intézett a vár ellen. 1588-ban még 36 német és 30 magyar gyalogos katona védte. ${ }^{63} \mathrm{Az} 1594$. évi, Nádasdy Ferenc féle védelmi tervezetben is szerephez jutott a kolostor. ${ }^{64}$ Kanizsa eleste után (1600) Csákányon és Pogányszentpéteren együtt 100 hajdú és 100 huszár állomásozott. ${ }^{65}$ Egy 1812-böl való térkép még ábrázolja négyszögletű árkát, romjairól Fényes Elek is megemlékezett, ma felszíni nyomai nem láthatók. ${ }^{66}$

Segesd ferences kolostorát, amely Báthori András tulajdonában volt, 1535-ben erődítették és 1566-ban pusztult el. 1570-ben a kolostor újabb erődítéséről értesülünk, immáron török kézen. ${ }^{67}$ Csányi Ákos Nádasdy Tamáshoz írott leveleiben, 1555 után több ízben említi az erődítés megerősítésének és a katonák létszámnövelésének szükségességét: „A segesdi klastromot nagynak mondják és palánkját is oly nagy helyen mondják, hogy ezer ember beleférne." ${ }^{68}$ A magyarok az erődítés viszszafoglalásával próbálkoztak $(1574,1586)$ eredménytelenül. A segesdi várat az 1618-19. évi zsoldlajstrom szerint 444 török őrizte. ${ }^{69}$

Az erődített kolostorok közé tartozott a Pogányszentpéteri70 és a Nagyszakácsi pálos kolostor is. Aszentpéteri apátság erődítése (Draveczky Balázs, Müller Róbert ásatása 1966-67) 1555-ben került szóba először. ${ }^{71}$ A nagyszakácsi kolostor négyszögletes sáncát egy 1812-es térkép ábrázolta.

Hasonlóan erődített lehetett a Lullai Szt. László ágoston-rendi prépostság, melyet Pesty Frigyes Ságvár DNy-i határában, a Klastromtető-dűlőben lokalizált. A háromszoros mély árokkal övezett, téglafalazattal körülkerített prépostság körül az 1812-es térkép sáncokat ábrázolt.

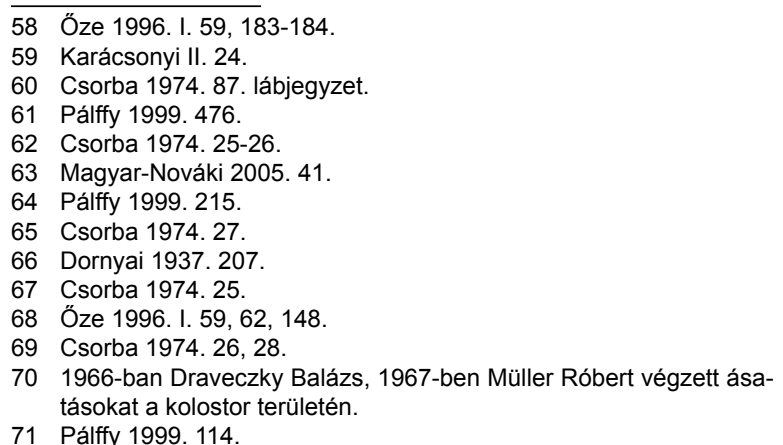




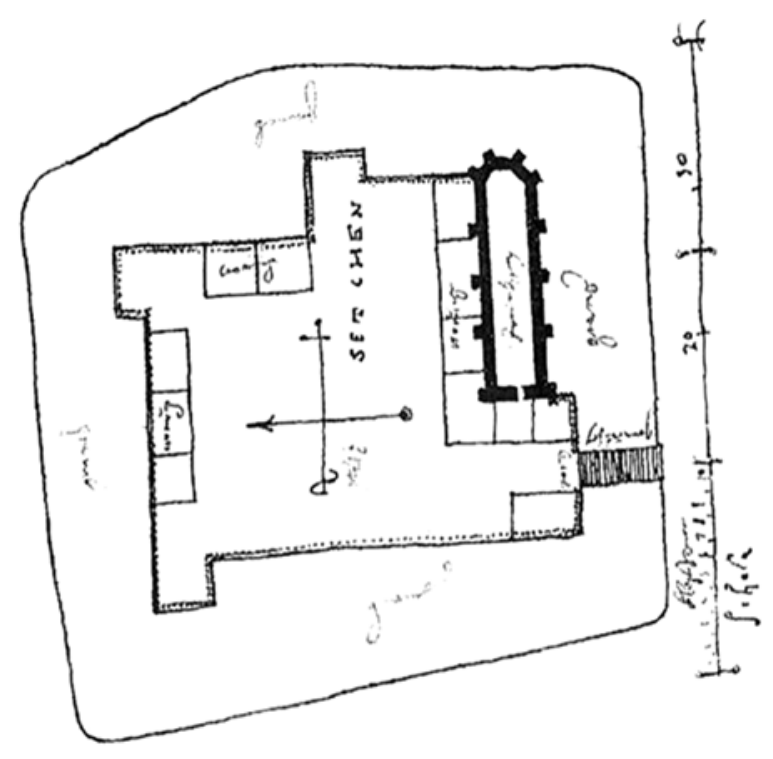

9. ábra: Giulio Turco felmérése a szőcsényi templomról

A kolostorokon kívül több egyszerű plébániatemplomot is felhasználtak harcászati célokra. Szőcsény templomának ábrázolása ugyancsak Giulio Turco jóvoltából maradt fenn. (9. ábra) A ma is álló kápolna a valamikori vártemplom K-i részének falcsonkjára épült rá, a várépület pedig É-ról csatlakozott a templomhoz. (10. ábra) A templom kutatását Lukács Zsuzsa végezte 1983-ban. A 12 támpillérrel ellátott, sokszög szentélyzáródású teremtemplom É-i és Ny-i oldalán teremsor húzódott. A palánkkal övezett belső vár kapuja DNy-ról nyílott, É és K-i részén még több helyiséget találunk. A külső vár sáncszerkezetű lehetett. A várat többszörös árokrendszer övezte, központi részét 2 belső árokkal osztották fel. K-i sarkában egy szögletes bástya állt. Az árkok szélessége 8-14 m, mélysége 3-5 m körül volt. 1548-ban a helytartótanács már erődítésként veszi számba. 1572-ből Palat Jeromos leírása ismert a várról és felszereléseiröl - ekkor 17 gyalogos zsoldoskatona szolgált, és hadifelszerelése 10 szakállas puskából (150

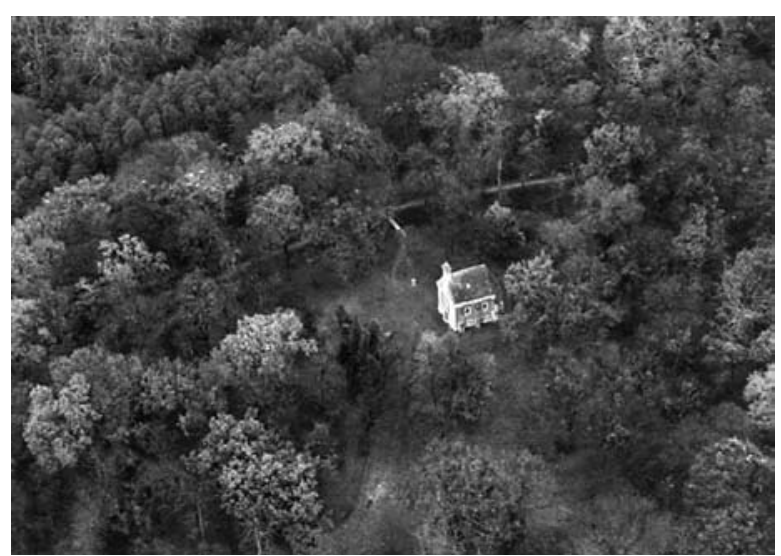

10. ábra: A szőcsényi templom maradványa a magasból (Civertan Bt.) golyóval), 1 sugárágyúból (5 golyóval), fél hordónyi puskaporból és kevés lőporból állt. A végvár árka ekkor 3,5 öl mély. ${ }^{72}$ 1581-ben az erődítményt már török kézen található, 1594-ben Zrínyi György a török által felgyújtott várat foglalta vissza. ${ }^{73}$
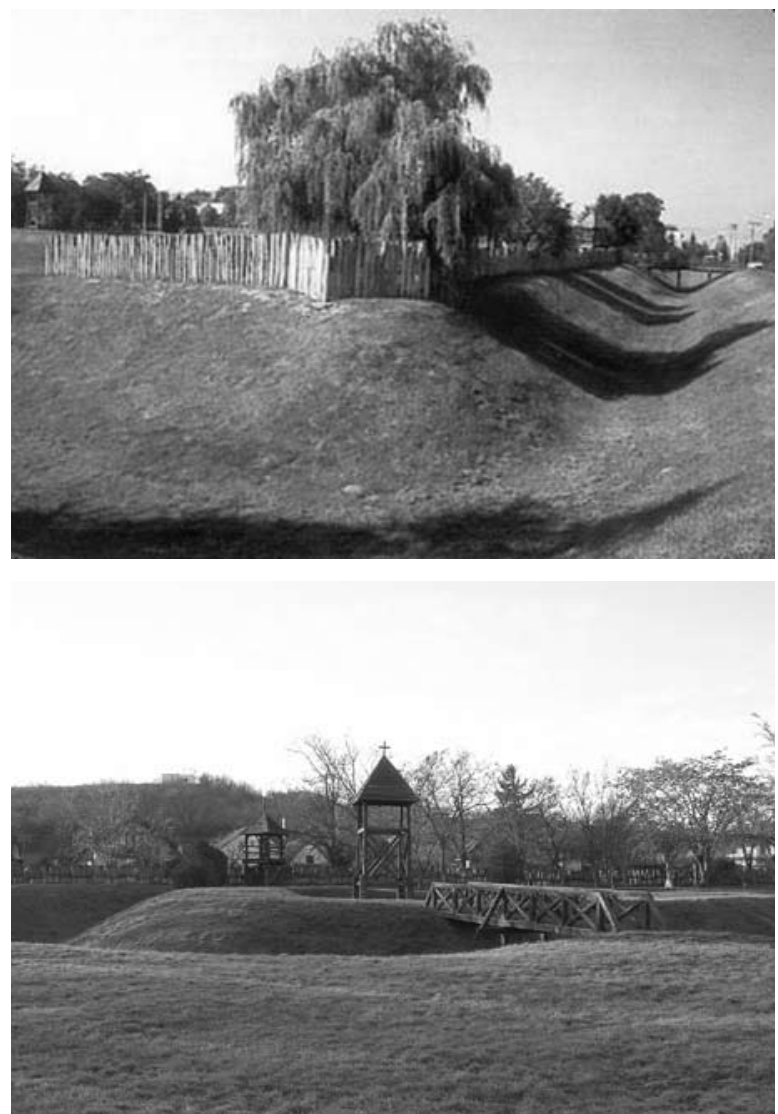

11. ábra: A fonyódi templomerőd mai állapota

Az 1544-7 körül megerődített Fonyódi plébániatemplom (Fonyód-Fácános) 100×112 m-es négyzetes, 4 sarokrondellás ${ }^{74}$ külső palánkját külső és belső várra osztották és árokkal övezték. (11. ábra) A 11-13 m széles és 2-3 m mély árokrendszer négyszög alakban vette körül a külső vár palánk falát. Ovális belső palánkját szintén vizesárok körítette. Első írásos említése 1548-9-ből származik, ekkor Magyar Bálint a várkapitány. 1551-ben Csányi 20 puskást küldött a várba, míg 1554-ben a vörsi hegyről (feltehetően a Bari hegyről van szó) letekintve ahonnan Fonyód és Somogyvár is látszott - Fonyód megerősítésének szükségességét érzékelte. ${ }^{75} 1555$ után, Kaposvár elestével a végvárrendszer első vonalába került. A kis erődítés 25 védővel 2 török ostromot is visszavert. 1571-ben 50 lovasa és 50 gyalogosa volt. Helyőrségét 1574-ben 40 gyalogos, 9 örmester, 2 tüzér és 3 egyéb

72 Veress 1996. 119, 122.

73 Magyar-Nováki 2005. 135.

74 Feld István e képződményeket méretük miatt nem tartja valódi rondelláknak, én is csak a terminológia hiányossága miatt használom ezt az elnevezést.

75 Öze 1996. I. 80, 110. 


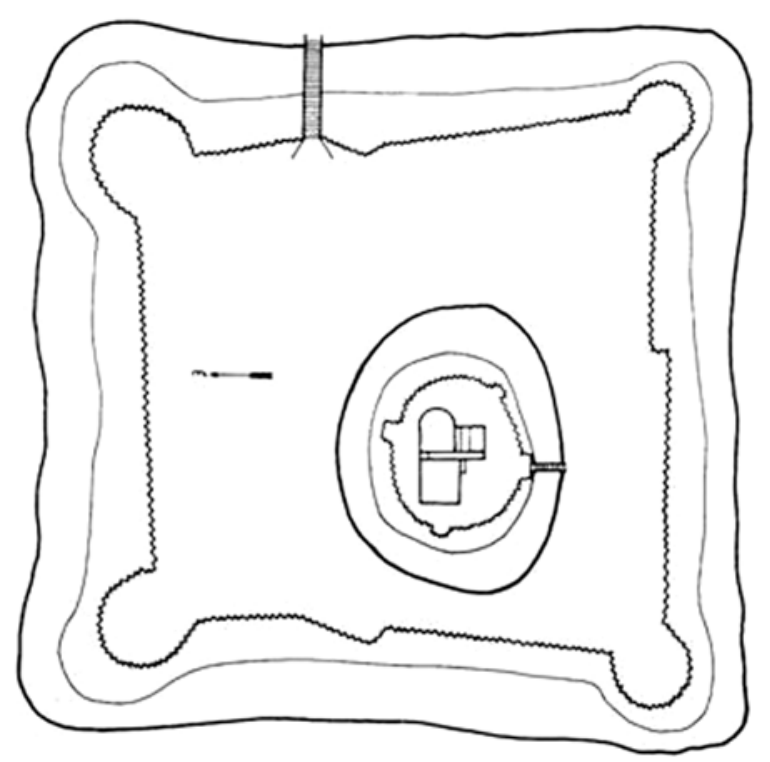

12. ábra: A fonyódi templom Giulio Turco felmérésén foglalkozású alkotta, ám az 54 fő mellett a hivatalos nyilvántartás alapján még 41 katona hiányzott (összesen 95 fö). Fonyód alatt Magyar Bálint katonai vizicsatákat is vívtak a törökkel. ${ }^{76}$ A Fonyódi erődítésröl Giulio Turco készített felmérést (1571-2). (12. ábra) 1572-ben, a már betegeskedő Magyar Bálintot Takaró Mihály váltotta fel a várkapitányi poszton, majd 1573-tól a birtokos, Lengyel András került az erődítés élére. ${ }^{77}$ Egy 1575 augusztus 6.-i levél tanúsága szerint már török kézen volt a vár, akik azt le is rombolták. Az erődített templom feltárását Fitz Jenő 1959-ben végezte.

Babócsa lerombolása és Szigetvár elzárása után, Csányi félelme szerint a török az Iharosi templomot fogja megerősíteni, amely a kanizsai út mentén, stratégiailag kedvező helyen, a legmagasabb ponton állt. 1557-i leveléből kitűnik, hogy vagy az egyház megerősítését, és várként való hasznosítását, vagy lerombolását véli üdvözítő megoldásnak. ${ }^{78}$

Somogysámson-Marótpusztán a Vári dülőben 2000ben Költő László kezdett meg ásatásokat, ahol a templomot és a temetőt Fonyódhoz hasonlóan egy $30 \times 30 \mathrm{~m}$ belső területü, 4 sarokrondellás földvár övezte. (13. ábra) Az ásató az erődítés megújítását az É-i oldalon tudta nyomon követni, ahol a korábbi keskenyebb árkot egy szélesebb sáncárok váltotta fel. $A$ vár bejárata $D$ felöl nyílt, ahol 4-5

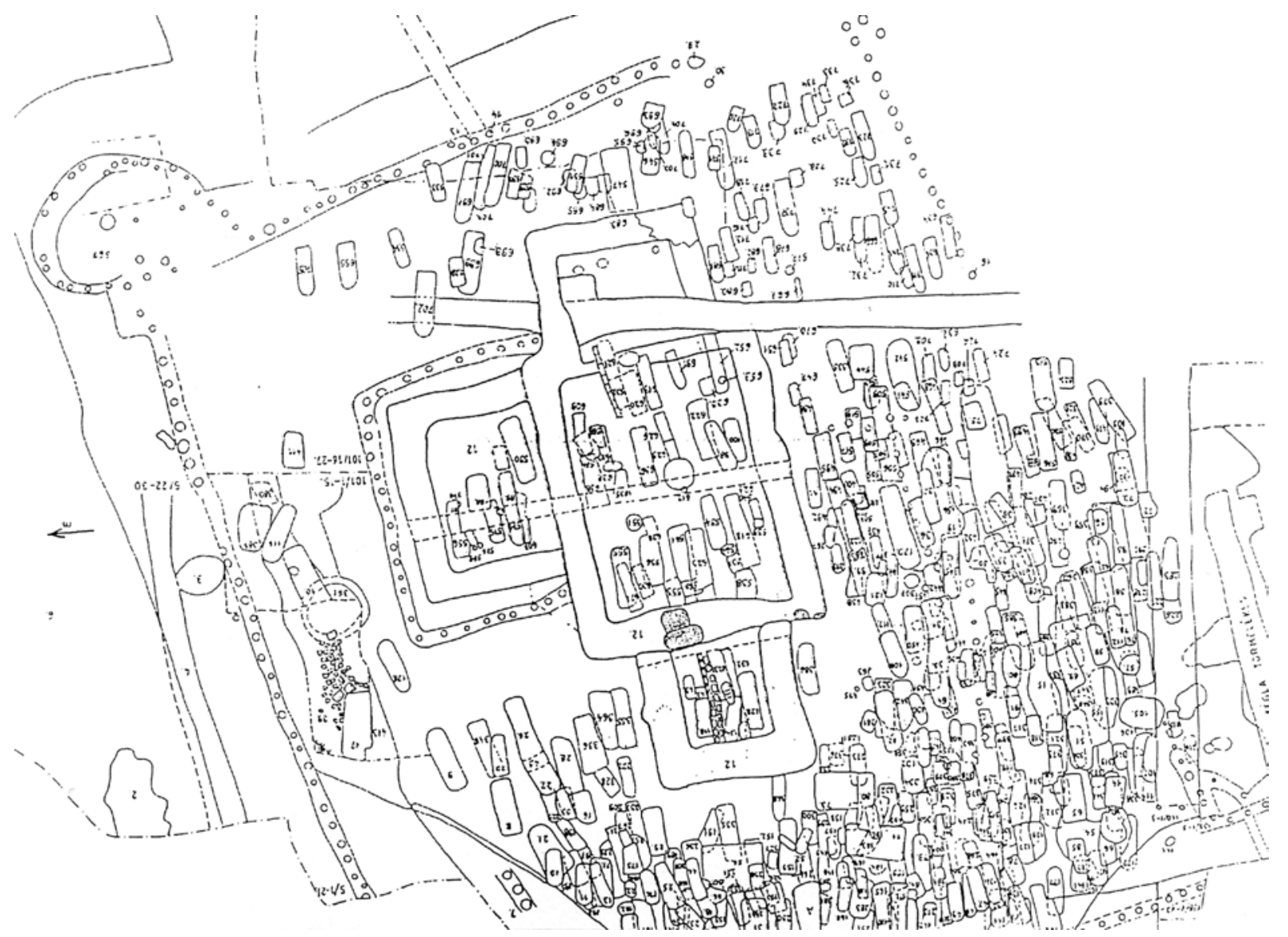

13. ábra: A somogysámson-marótpusztai templomeröd maradványai (Költő László ásatása)
76 E célra a Dráván, Berzencén és Bélavár környékén épített hajókat használtak. Öze 1996. I. 23, 125.

77 Pálffy 1999. 140.

78 Öze 1996 I. 338-339, 344-346 
m-re É-ra egy belső cölöpsor volt megfigyelhető. A sáncot támasztó cölöpsor árkát, valamint a sarokrondellákat beleásták a szélső sírokba. A 16. sz. közepére a plébániafunkció háttérbe szorult, bár a temetőt még az erődítmény pusztulása után is használták. Erődítésárkából 16. sz.-i érmék kerültek elő. ${ }^{79} 1548$-ban Nádasdy Tamás szemléje során dönteni kellett Marót, Szentjakab, Fajsz, Orda(csehi), Fonyód, Bajom, Mesztegnyő, Szőcsény és Csákány váráiról, vajon a védelem számára felhasználhatóak, vagy lerombolásra ítéltetetnek. ${ }^{80} \mathrm{~A}$ vár birtokosa ekkor Nagymaróti Komornyik János volt. Nádasdy 1555ben készített felmérésében castellumként szerepelt.81 Egy 1559. februári levélböl Marót hadnagyát említik, míg 1562-ben Magyar Bálint a kismaróti katonák ellen emelt panaszt. ${ }^{82}$ Feltehetően 1566 őszén került török kézre Babócsa, Berzence, Vízvár, Zákány, Segesd, Szenyér, Marcali és Lak váráival együtt.

Buzsák-Fehérkápolna elnevezésű műemléképület kutatását 1983-ban B. Benkhard Lilla és Lukács Zsuzsa végezték. A templom azonosítása problematikus - a Fehérkápolna elnevezés nem a település nevére (Fehéregyháza település Karád mellett található), hanem templomának színére/anyagára utal, amely talán a három, egyházzal is rendelkező Kölked egyikének kápolnája lehetett. A temetőt körülvevő egykori ovális körítőfalon kívül egy árokkal övezett, sarokbástyás palánkerődítés látszik, amelyet a kutatók a török időkre datáltak. ${ }^{83}$

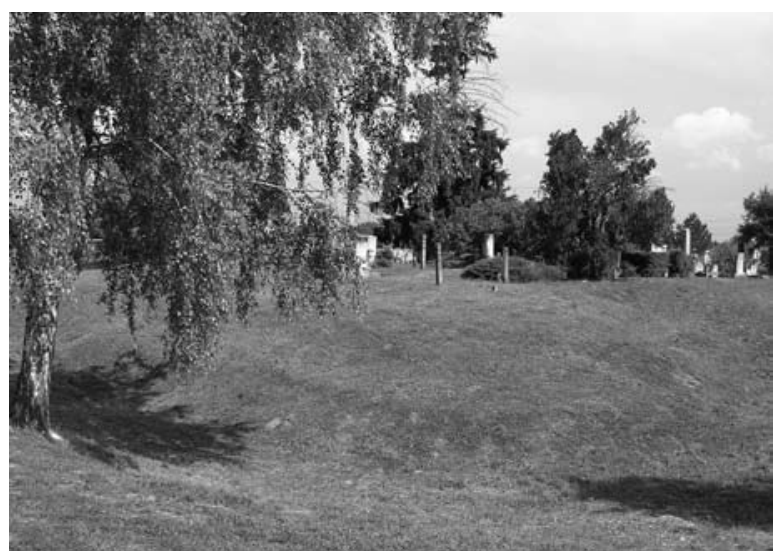

14. ábra: A nagybajomi erődítés sáncmaradványai a református temetőben

Ugyancsak erődített temploma volt Nagybajomnak, melynek félköríves sáncmaradványai a református temető D-i sarkában helyezkednek el, és amelyet a II. József-féle katonai felmérés másodlagos funkciója alapján várromként jelölt. (14. ábra) Téglalap alakú erődítését É, Ny és $D$ felöl árok övezte. Feltehetően egy külső palánk meglétével is számolhatunk, hiszen egyik földesurának, a Várdaiaknak állt itt házuk. ${ }^{84} \mathrm{Az}$ erős-

79 Költő 2005. 289-290.

80 Pálffy 1999. 13. táblázat, 19. jegyzet.

81 Pálffy 1999. 117.

82 Őze 1996. I. 310, II. 392.

83 RRM Adattár 449. Ásatási és Műemléki jelentés

84 Aradi 1997. 6-7. ség 1543-tól a török elleni háborúk kapcsán tünik fel forrásainkban. ${ }^{85}$ 1550-től Csákányhoz hasonlóan Allya Mátyáshoz tartozott. 1554-ben a települést felégetik, ugyanakkor castellumát még 1555-ben is említik. Végleges pusztulása Korotna török általi birtokbavételével következett be. ${ }^{86}$

Balatonboglár templomának erődítéséröl 1614-ben hallunk, amikor Molart a budai pasához írott panaszában megemlíti, hogy a törökök itt a pusztaszentegyházból palánkot építettek. ${ }^{87} \mathrm{~A}$ boglári várszerűen erődített egyház feltárását 1937-8 között Dornyai Béla, 1996ban Jankovich $B$. Dénes végezte.

Ságvár templomerődjét Takaró Mihály jelentései alapján ismerjük. Középkori templomát, melyből a török kastélyt épített és 8 védővel felszerelt, Takaró Mihály tihanyi kapitány 1557-ben elfoglalta és felrobbantotta. ${ }^{88}$ 1558-ban Takaró Mihály beszámolója alapján a török az egyházat egy éjszaka alatt megerősítette, ám ő ezt egy óra alatt visszafoglalta. Talán csak a templom kapujának eltorlaszolását jelenthette az erősítés. ${ }^{89}$ Ságvár valamikori temploma a Jaba-patak túlsó oldalán, a belterülettől DNy-ra, a Bogárházi-völgy-Malomhegy nevü területen állt. ${ }^{90}$

Somogysimonyinál 1572-ben a törökök kívánták az egyházat várrá alakítani - felvonóhidas kapuja már elkészült, amikor a magyarok Bornemissza János kanizsai várkapitány vezetésével felrobbantották. ${ }^{91}$

Szólád templomát a 16-17. sz.-ban kettős sánccal erődítettek. A belső árok szélessége 7-8 m, mélysége 1-1,5 m; - töle ÉK, K-re egykori sírok nyomai láthatók. ${ }^{92}$ A Köröshegyi Szt. Kereszt bencés egyház sánccal való erődítéséről egy 1812. évi leírásból értesülhetünk. ${ }^{93}$ A templom és erődítése homokbányászás következtében pusztult el. A Tapsonyi határba beleolvadt Terebezd templomának helyénél szintén „Török sáncokat” említenek. Feltehetően hasonlóan a templom erődítése során várt váras településsé Balatonszentgyörgy. 1555-ben Nádasdy Tamás Sulyok Balázs és István kezén említi a várat. ${ }^{94}$ 1565-ben Csányi Ákos Nádasdy hitvesének, Kanizsai Orsolyának írott levelében már a vár pusztulásáról számol be. ${ }^{95} \mathrm{~A}$ Báthori András birtokában lévő Marcali erődítését a török ellenes hadjáratok során többször említik, a 16. sz. második felétől megerősítésére több alkalommal is törekedtek. ${ }^{96}$ Temploma a Historia Domus tanúsága szerint erődített volt. Babócsához hasonlóan az erődítés mind a templomot, mind a Marcaliak által még a 13. sz. végén épített udvarházat is magába foglalta, amelyet már 1456-ban várrá alakítottak.

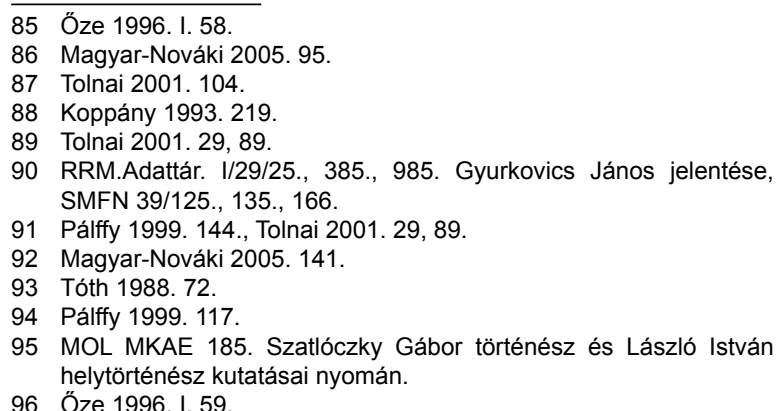


1526 utánra keltezhető a palánk megerősítése, amely 1566-ban török kézre került. ${ }^{97} \mathrm{~A}$ nagyobb területet is magukba foglaló erődítéseket azért érdemes mégis az erődített templomok társaságában megemlíteni, mivel az erődítés magja a templom, illetve annak tornya volt, így az egyházi épület kiemelkedő szerepet játszott az erődítés létrehozásában.

Törökkoppány elöször 1552-ben került török kézre, amikor 57 ulufedzsi (nehéz lovas) és 29 szerb martalóc (könnyűlovas) állomásozott a koppányi várban. A feljegyzés alapján Törökkoppányban már a török idők előtt állt erődítés, melyet feltehetően Török Bálint, korábbi birtokosa emelt. Aszigetvári helyőrség még ebben az évben visszafoglalta a várat, amely végleg Tujgun budai pasa 1555 évi hadjáratának esett áldozatul. ${ }^{98}$ A török alatt a település szandzsák székhelyként müködött, amelyhez 5 nahie tartozott (Koppányi, Dombóvári, Karádi, Köröshegyi és Marcali) összesen 190 faluval. Minden nahie székhelyet megerősítettek és helyőrséggel láttak el. Az 1558 évi zsoldos jegyzék szerint 58 nehéz lovas szolgált a várban, 1565-ben őrsége 123 fős volt, míg 3 évvel később 115 fő védte (36 janicsár, 31 azáb (lándzsás gyalogos) és 48 ulufedzsi). ${ }^{99} \mathrm{Az}$ erődön 1587-ben rajtaütöttek a magyarok, de 2 év múlva ismét török kézen találjuk. ${ }^{100}$ 1597-ben szandzsákbégjének, Dervisnek nyugdíjazásáról értesülünk. ${ }^{101}$ Evlia Cselebi 17. sz. közepi leírása alapján tudjuk, hogy „Koppány sík helyen épült, ötszög alakú, erős építésü, kőből készült vár." Egyetlen kapuja nyugaton nyílt. Nemcsak a várat, hanem magát a várost is övezte töméspalánk, sarkain „félelmes” bástyákkal. ${ }^{102} \mathrm{~A}$ rkat. templom kertjében folytatott tereprendezés során talán az erődítéshez tartozó falnyomokat találtak. ${ }^{103} \mathrm{~A}$ török (Ahmed bég) a Felsőendrédi templomot és környezetét is átalakította hadi célokra. A templomot ekkor kettős palánkból készült négyszögletes védmü övezte. Az 1756-ban újjáépített templom egyik fala őrzi még az erődítésnyomokat. A plató DK-i és ÉK-i szélét mesterségesen kialakított meredély övezi, DNy felöl pedig mély árok nyomát észlelhetjük. Az alsó vár ÉK felöl csatlakozik a területhez. A település várában 130 török katona állomásozott. 1613-ra ez a szám 36 lovas és 36 gyalogosra fogyatkozott. Utoljára 1686-ban említették mint török végvárat. ${ }^{104}$

Az 1570-es évekre a törökök is kiépítették saját várrendszerüket, amelybe Somogy megyében a fentieken kívül Lak, Bézseny, a szemesi Bolondvár és Karád is beletartozott. A török őrség számbeli fölénye mindenütt nyomon követhető. A törökök a keresztényekhez hasonlóan, megpróbálták az erődíthető templomokat is bevonni várláncolatukba.

\footnotetext{
97 Magyar-Nováki 2005. 86.

98 Vass 1972.57

99 Vass 1972. 59.

100 Pálffy 1999. 156.

101 Pálffy 1999. 212. A rajtaütésröl Id. Pesty 2001. 344-6.

102 Vass 1972. 58.

103 Magyar-Nováki 2005. 147.

104 Magyar-Nováki 2005. 26.
}

\section{Az egyházi élet hanyatlása a törökkor küszöbén}

A török elleni hadjáratok forrásanyagából az is kitünik, hogy az egyház nem támasztott számottevő akadályt a kolostorok, templomok erődítését illetően. Ennek egyik oka lehetett az egyházszervezet felbomlása, ugyanakkor nem lehet figyelmen kívül hagynunk a 16 . sz. közepén a papok és szerzetesek létszámában bekövetkező drasztikus csökkenést sem. Mindenütt az erkölcsi hanyatlás jelei mutatkoztak. 1560-ban a Somogy megye szomszédságában fekvő Zalavári apátságnál nincs pap, Kapornakon pedig egy „inas szerzetes” munkálkodott. ${ }^{105}$ Hedrehelyen, mint már az előzőekben említettük, egyetlen öreg szerzetes élt.

Néhány adat a törökké lett papokról is tudósít. Veszprém bevételekor Lörinc pap a törökhöz állt át és számukra kémkedett. ${ }^{106}$ 1555-ben Magyar Bálint Köröshegyen egy törökké lett papot fogott el. ${ }^{107}$ Ugyanebben az évben István koppányi pap Naszuf török bég által kinevezett püspök, és a még meg nem hódított nyugat somogyi településeket a török iránti lojalitásra buzdította. ${ }^{108}$ A somogyvári paptól Csányi szerint gonoszsága miatt el kell venni a plébánosságot. ${ }^{109}$

\section{Összegzés}

Összegzésként elmondhatjuk, hogy az Árpád-korra datálható erődített templomok létét Somogyvár kivételével a megyében nem tudjuk bizonyítani. A 14-15. sz.-ból azonban mind írásos forrásokból, mind pedig ásatásokból, valamint terepbejárások nyomán bizonyíthatóan megugrik ezen erődítések száma - talán az Árpád-ház kihalása utáni zavargások, illetve a hatalmaskodások hatására mentsvárként kezdenek funkcionálni a templomok. Az ország más vidékein a templomok, apátságok erődítése már a tatárjárás körüli időszaktól nyomon követhető (pl. Tihany, Egres), Somogyban talán a kisebb pusztulás miatt erre csak későbbi adataink vannak. Ezek erődítése nem egy esetben nem tér el látványosan a török elleni háborúk során megerődített egyházakétól - minimális programként sánc és árok övezte a templomot, a fejlettebb erődítéseknél pedig négyszögletes palánk, illetve sarkain rondellaszerü torony is járult a megerősítéshez. Esetenként többszörös sáncárokrendszer, esetleg palánk épült 1-1 templom köré, külső és belsővárra tagolva az azt övező területet. Somogyban adottságai miatt kő/téglafalat ritkán alkalmaztak. A második fázisban szembe tűnő a kolostorok, monostorok végvárként való alkalmazása (szinte az összes létező kolostor ekkor másodlagos funkciót kap), ami feltehetően jobban kiépített mivoltukkal volt

\footnotetext{
105 Mindkét helyen még tudatlan „alávaló papok is foglalkoztatva vannak".Őze 1996. II. 187-189. Már ezt megelőzően, az 1508-as vizitáció is sötét lépet festett a somogyi bencés monostorokban zajló hitéletről. Ld. PRT. III. 617.

106 Öze 1996. II. 340-341

107 Öze 1996. I. 163-165

108 Vass 1972. 58., Maksay 1969. 129-130. „István, Isten kegyelméből, a hatalmas török császártól Koppány megyében választott Koppányi püspök." A települések Kéthely, Marcali, Kanizsa, Csákány, Mesztegnyő és Szenyér voltak.

109 Őze 1996 II. 227-228.
} 
összefüggésben. Egy újonnan létrejött erődítés katonai ellátottsága azonban így is messze alulmaradt a török végvárak viszonylatában, bár formájukban azonosak. ${ }^{110}$ A somogyi végvárrendszer 1558-ra már oly mérték-

110 Koppányban a kivonható lovasok száma is elérte a 400 föt, míg 1559 augusztusában 1000 lovast mozgósítottak. Ezzel szemben a magyar végvárak esetében nem számolhatunk 100 lovasnál többel, amihez természetesen gyalogos katonaság is járult. Öze 1996. I. 62 , II. 79 . ben összeomlott, hogy Pácod, Korotna, Kaposvár, Somogyvár, Méró, Mesztegnyő és Bajom erődítései vagy török kézre kerültek, vagy rommá váltak és csak Fonyód, Lak, Marcali, Segesd, Szenyér, Szigetvár és Babócsa voltak a keresztények birtokában.

\section{Irodalom}

ANJOU-KORI OKMÁNYTÁR. I-VII. (szerk. Nagy I.- Tasnádi Nagy Gy.) 1878-1920. Budapest

ANJOU-KORI OKLEVÉLTÁR. Documenta Res Hungaricas tempore regum Andegavensium Illustrancia. Szerk.: Kristó Gy. et al. Szeged. 1990-2001.

ARADI Cs. 1997: Adalékok a Várday család XIII-XVI. századi történetéhez. Levéltári Évkönyv Somogy Megye Múltjából 28. 1997. Kaposvár. 3-10.

BÉKEFI R. 1907: A Balaton környékének egyházai és várai a középkorban. A Balaton Tudományos Tanulmányozásának eredményei. 3. kötet. 1907. Budapest

B. BENKHARD L. és LuKÁCs Zs. 1996: Lengyeltóti plébániatempIom. TKM. 549. 1996.

BelénYesy K., Marton T. és Oross K. 2002: BalatonszárszóKiserdei-dülő. - In: A tervezett M7 autópálya Somogy megyei szakaszán 2000-2001-ben végzett megelőző régészeti feltárások előzetes jelentése. II. (szerk.: Király I. Sz.) Somogyi Múzeumok Közleményei. Kaposvár 2002. 9-14.

Csorba Cs. 1974: Erődített és várrá alakított kolostorok DélDunántúl török kori végvári rendszerében. Levéltári Évkönyv Somogy Megye Múltjából. 1974. Kaposvár. 13-47.

Docummenta Artis Paulinorum 1-3 kötet MTA Müvtört. Csoport Forráskiadványa XII-XIV.kötet. 1976

DoRnYAl B. 1937: A somogymegyei Szőcsény és Csákány várairól. - Vasi Szemle 1937. 4. 204-213.

EGYHÁZTÖRTÉNETI EMLÉKEK A MAGYAR HITÚJITÁS KORÁBÓL. I-V. (sZerk.: Bunyitay V.-Karácsonyi J.-Kollányi F.-Lukcsics J.-Rapaics R.). Budapest. 1902-1912.

JANKOVICH B. D. 1976: Adatok a Rinya völgy középkori településtörténetéhez. - Levéltári Évkönyv Somogy Megye Múltjából. 1976. Kaposvár. 3-31.

KARÁCSONYI J.: Szt. Ferenc rendjének története Magyarországon 1711-ig. I-II. Budapest. 1922-1924.

KöLtő L. 2005: 16. századi templom körüli temető feltárása Somogysámsonban. - In: Ritoók Á.-Simonyi E. szerk: „...a halál árnyékának völgyében járok”. A középkori templom körüli temetők kutatása. Opuscula Hungarica VI. Budapest 2005. 289-295.

KopPÁnY T. 1993: A Balaton környékének mủemlékei. Művészettörténet és műemlékvédelem III. 1993. 195-225.

KuBINYI A. 2005:Késő középkori temetkezések a történeti forrásokban. - In: Ritoók Á.-Simonyi E. szerk: „....a halál árnyékának völgyében járok". A középkori templom körüli temetők kutatása. Opuscula Hungarica VI. Budapest 2005. 13-18.

KUMOROVITz L. B. 1964: A zselicszentjakabi alapítólevél 1061ből: „Pest” legkorábbi említése. Tanulmányok Budapest Múltjából 16. 1964. 43-83.

LuKÁCs Zs. 1992: Előzetes beszámoló a Lengyeltóti római katolikus templom 1991. évi kutatásáról. Múemlékvédelmi Szemle. 1992/1. Budapest. 19-30.

MAGYAR K. és NovÁKI Gy. 2005: Somogy megye várai a középkortól a kuruc korig. Kaposvár 2005.

MAKSAY F. 1969: István „koppányi püspök”. Történelmi Szemle 1969. 1-2. 129-130.
Mezö A. 1996: A templomcím a magyar helységnevekben. (1115. sz.) Budapest 1996.

Öze S. 1996: 500 magyar levél a XIV. századból. Csányi Ákos levelei Nádasdy Tamáshoz 1549-1562. I-II. Budapest. 1996.

PÁlfFY G. 1999: A császárváros védelmében. A győri főkapitányság története 1526-1598. Győr. 1999.

PESTY F. 2001: Somogy vármegye helynévtára. Fontes Comitatus Simighiensis 1. Szerk.: Bősze S. Kaposvár. 2001.

ERDÉLYI L. és SöRös P. szerk.: A pannonhalmi Szent Benedek rend története. I-XII/B. kötet. 1902-16. Budapest

RÁcz Gy. 2001: Az Árpádok korától a török megjelenéséig. - In: Bősze S. szerk: Nagyatád Monográfiája I-II. 2001. Nagyatád. 64-97.

Rıтоóк Á. 1977: Falusi templom körüli temetök. - In: Folia Arch. XLVI. 1977. 165-177.

Rupp J.: Magyarország helyrajzi története fö tekintettel az egyházi intézményekre, vagyis a nevezetesb városok, helységek és azokban létezett egyházi intézetek püspökmegyék szerint rendezve. I-III. Pest-Budapest. 1870-1876.

SMFN = Végh J. szerk.: Somogy megye földrajzi nevei Budapest. 1974

SMM-B. 79 = Borsa I.: A szenyéri uradalom Mohács előtti oklevelei. Levéltári Évkönyv Somogy Megye Múltjából. 10. 1979. Kaposvár. 59-150.

SMM-B. 83 = Borsa I.: A Somogy Megyei Levéltár Mohács elötti oklevelei. Levéltári Évkönyv Somogy Megye Múltjából. 14. 1983. Kaposvár. 3-82.

SMM-B. 89 = Borsa I.: Királyi rendeletre tartott megyei közgyűlés Somogyvár mellett 1444-ben. Levéltári Évkönyv Somogy Megye Múltjából. 20. 1989. Kaposvár. 5-28.

SMM-B. 2002 = Borsa I.: A somogyi konvent oklevelei az Országos Levéltárban. (1421-1440) Levéltári Évkönyv Somogy Megye Múltjából. 33. 2002. Kaposvár. 7-58.

SMM-K. 79 = Komjáthy M.: A somogyi konvent II. Ulászló kori oklevelei az Országos Levéltárban. Levéltári Évkönyv Somogy Megye Múltjából. 10. 1979. Kaposvár. 51-58.

ToLNAI G. 2001: Templomvárak, erődtemplomok Magyarországon. Esztergom. 2001

То́тн P. 1988: Somogy vármegye leírása 1812-böl. Levéltári Évkönyv Somogy Megye Múltjából. 19. 1988. Kaposvár. 41-91.

VALTER I. 2004: Árpád-kori téglatemplomok Nyugat-DunántúIon. Budapest. 2004.

VAss E. 1972: Törökkoppány 1556. évi első török adóösszeírása. Levéltári Évkönyv Somogy Megye Múltjából. 3. 1972. Kaposvár. 57-73.

VERESS Cs. 1996: Várak a Balaton körül. Budapest. 1996.

ZıchY OKMÁnYTÁr. A Zichi és Vászonkeői Gróf Zichy család idősb ágának okmánytára. (Magyar Történelmi Társulat) szerk.: Nagy I.-Nagy I.-Véghely D. I-XII. Pest-Budapest. 1871-1931.

ZsIGMOND KORI OKLEVÉLTÁR (szerk.: Mályusz E.-Borsa I.) I-IV. Budapest. 1951-1994. 


\title{
The research of medieval fortified cloisters and churches in Somogy county
}

\author{
CSILLA M. ARADI
}

The two groups of Hungarian fortified churches are separated from each other not only functionally, but from the chronological aspect as well. Whereas during the Late-Medieval period churches and cemeteries acted as storage of value and refuge centers, from the 16. C. they became part of the fortress system built against the Turks.

Medieval fortified churches already recognized from written sources became tangible through archaeological excavations and field survey. We gained knowledge of charters, coins, chalices, attire and other valuables preserved in parishes, monasteries or cloisters through lawsuits due to harassment. It was also not uncommon to build farm buildings or cellars in cemeteries, as was demonstrated through excavations. At Balatonszárszó the church and the cemetery was encircled by a 4-6 $\mathrm{m}$ wide and 2-3 $\mathrm{m}$ deep fosse, which from the inside was accompanied by diagonally built pole framed houses. These buildings had a function of grain storage and refuge.

While Benedictine monasteries were fortified by stone walls prior to the 15 C. (e.g. Szentjakab, Somogyvár), other cloisters were strengthened during the period of Turkish war. These fortifications - due to the lack of time - were hastily prepared and therefore were of temporary nature, with a mere fosse or with an additional palisade (e.g. Mesztegnyő, Csákány). The churches built from solid building material (bricks or stone) and furnished with a tower were suitable for military purposes. In the fortified churches regular guards were placed. These became part of the fortress system, while cloisters not in use were demolished. An excellent example of 16. C. church fortification was the parish church of Fonyód, where an outer palisade with 4 corner bastions and a fosse encircled the oval formed inner palisade. A similar structure was excavated at Somogysámson-Marótpuszta in 2000 (Költő L.).

Written documents and field survey give evidence that a great number of parish churches were also formed into fortresses. This proves that in the mid 16. C. church organization was already loosing its function, at least in parts exposed to Turkish attacks. The Turks themselves also used churches for their fortifications, as seen in the case of Törökkoppány - a later nahie center - where the town itself was encircled by a palisade with corner bastions.

It can be stated that the form of the fortifications of the 2 periods have much in common. As part of a minimal program earthworks with fosses were built, while a more elaborate rectangular palisade with corner bastions and fosse, dividing the territory into outer and inner castle area, was not infrequent. 